$$
S D 143
$$

As

1917 



\title{
SOME TIMELY SUGGESTIONS FOR THE OWNERS OF WOODLOTS IN NEW ENGLAND.
}

\author{
BY \\ F. H. MOSHER, Entomological Assistant,
}

AND

G. E. CLEMENT, Assistant in Forest Management, Gipsy Moth and Brown-tail Moth Investigations. 
D. ถะ I.

JUN $12 \quad 1917$ 


\title{
UNITED STATES DEPARTMENT OF AGRICULTURE.
}

\author{
BUREAU OF ENTOMOLOGY.
}

L. O. HowARD, Entomologist and Chief of Bureau.

\section{SOME TIMELY SUGGESTIONS FOR THE OWNERS OF WOODLOTS IN NEW ENGLAND.}

By F. H. Mosher, Entomological Assistant, and G. E. Cuement, Assistant in Forest Management, Gipsy Moth and Brown-tail Moth Investigations.

Farmers and other woodlot owners in New England have, at tho present time, an unusual opportunity not only to realize appreciable sums from their timber but also to better the condition of their woodlands and lessen the liability of their being attacked by the gipsy moth. Because of the increased demand for cordwood it is now possible to dispose of classes of material not ordinarily merchantable, and while labor is scarce and high priced the increased cost of getting out cordwood, it is believed, will be offset by the higher value of the wood. For these reasons timber owners, by puting into effect a few simple rules regarding the handling of their timber, will often be able to accomplish all the following objects at one time:

First. A large amount of low-grade wood can be disposed of to the advantage of the owner.

Second. A better class of trees with improved growing conditions will be provided by the remoral of inferior trees now standing.

Third. The numbers of gipsy moths may be reduced by the removal of those trees of which they are particularly fond and upon which they thrive particularly well.

In cutting cordwood heretofore, the practice generally has been to cut clean. Where most of the trees on an area are mature, dead, dying, or defective, a contimuation of this practice is to be recommended, but where a large number of young trees are standing it is often preferable to thin judiciously. Such thinning should be based on several considerations, among which are:

1. All dead, dying, and defective trees should be cut to make room for live trees, and in the case of dying trees, to check the development of injurious insects which may breed in them. 
2. Species of trees having the highest commercial value should be given every opportunity to grow and develop well. All other trees interfering with their growth and development should be removed.

3. Most trees to grow to the best advantage need a largo amount of light. A thinning should aim to space the trees so that each individual shall have a proper amount of light.

4. The foliage of certain species of trees is more desired by gipsy moths than that of other species. The removal of such trees may often afford relief from these pests.

5. The price of lumber is rising, and the value of woods of good quality will rise correspondingly. Thinning may often be a great help in the production of such woods, besides increasing the rate of growth.

6. Cutting clean is injurious to forest soil, and a long time must elapse before another cut can be grown. Since no one can predict how long war conditions will last, it seems advisable to cut gradually, removing the poorest trees first and saving the better ones for higher prices.

There are 75 species of native and naturalized trees growing in this region. Realizing their varying liability to gipsy-moth attack, the Bureau of Entomology has conducted extensive laboratory experiments for a series of ycars to determine the susceptibility of each of these species. It has been found that the small caterpillars will not feed on certain kinds of foliage, although they may seriously injure the same trees after becoming nearly full grown. Other trees are eaten freely by caterpillars of all sizes, while some foliage is nerer attacked.

All of the laboratory experiments were supplemented by extensive obscrvations on the feeding of the caterpillars in the field, and from the data secured the forest trees have been grouped in the following classes:

CLASS I.-Species that are fatored food of gipsy-moth larvæ in all their stages.

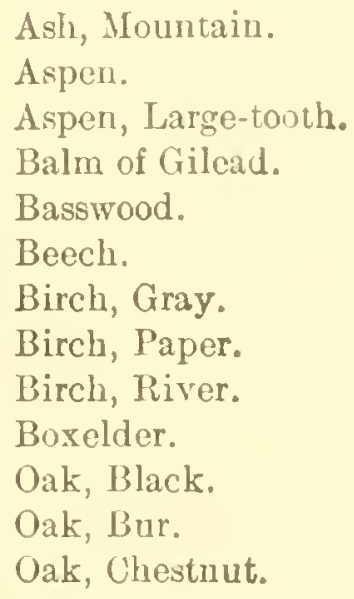

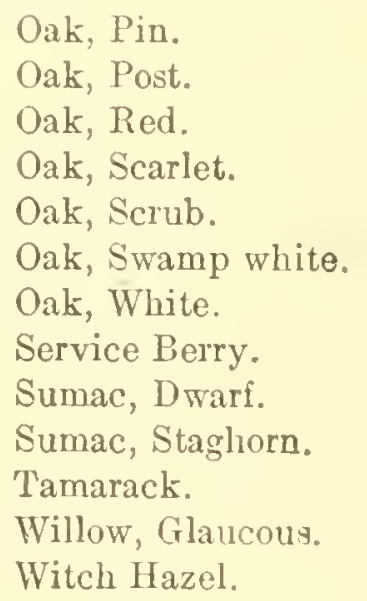

Cuass II. - Species that are favored food for gipsy-moth larvæ after the earlier larva stages.

\author{
Chestnut. \\ Hemlock. \\ Pine, Pitch. \\ Pine, Red.
}

Pine, White.

Spruce, Black.

Spruce, Red.

Spruce, White. 
CLASS III.-Species that are not particularly favored, but upon which a small proportion of the gipsy-moth larre may develop.

Beech, Blue.

Birch, Black.

Birch, Yellow.

Cherry, Black.

Cherry, Choke.

Cherry, Wild red.

Cottonwood.

Elm, American.

Elm, Slippery.

Gum, Black.
Hickory, Bitternut.

Hickory, Mocker-nut.

Hickory, Pignut.

Hickory, Shagbark.

Hop Hornbeam.

Maple, Red.

Maple, Silver.

Maple, Sugar.

Poplar, Silver.

Sassafras.

CLAsS IV.-Species that are unfavored food for gipsy-moth larvæ.

Arborvitæ.

Ash, Black.

Ash, Red.

Ash, White.

Balsan Fir.

Butternut.

Cedar, Red.

Cedar, White.

Dogwood, Flowering.

Hackberry.

Holly, American.
Laurel, Mountain.

Locust, Black.

Locust, IIoney.

Maple, Mountain.

Maple, Striped.

Mulberry, Red.

Sheepberry.

Sycamore.

Tulip.

Walnut, Black.

The gipsy moth is such a serious pest orer a large portion of New England that the varying extent to which it feeds on trees of different species is a very important factor in determining what trees shall be removed and what ones preserved in thimning. Other factors affecting such determination are the commercial value, rapidity of grewth, and adaptability to different soil conditions of different species of trees. With these several factors and 75 species of trees occurring in a multitude of combinations, it can be seen how impossible it is to outline any plan of thinning which will be applicable in all cases. An attempt is made here, howerer, to indicate in a general way some of the qualities of each species which must be considered in thinning.

\section{TREATMENT OF TREES IN CLASS I.}

Beginning with Class I of the foregoing classification, it is found to be composed of 26 species which are favored as food by gipsy-moth larra. Ten of these species, namely, mountain ash, gray birch, river birch, boxelder, scrub oak, service borry, dwarf sumac, staghorn sumac, glaucous willow, and witch hazel are of little commercial value and should be removed.

Ten of the species in this class are oaks, including the scrub oak just mentioned. Oaks growing on light soils and rocky ridges are usually not very vigorous, grow slowly, and suffer severely from gipsy-moth attack. 
'The bur oak, chestnut oak, pin oak, post oak, and swamp white oak are generally more or less rare and of restricted local occurrence in this region, so that they have no great commercial importance. Owing to their great susceptibility to moth attack these trees should be cut in every case where they are interfering with the growth of better trees, or where there is an opportunity to replace them with trees nót so liable to moth attack.

The white oak reaches the northern limit of its range in the gipsymoth infested region, yet it is one of the most abundant of the oaks. Its foliage seems to be particularly desired by the gipsy moth, and it grows very slowly. For these reasons it is not a desirable type for growth in this region.

The red, black, and scarlet oaks grow well and produce a valuable class of material. Where young, vigorous trees of these species occur on good soil in mixture with other trees, they may be left, despite their liability to gipsy-moth attack, providing that they are not interfering with the growth of more valuable trees.

Aspen, large-tooth aspen, and balm of Gilead can not tolerate shade, and they grow well only where they have free access to plenty of light. Scattered specimens in mixed woods may well be cut, but pure stands, which occur occasionally, may be left to mature when they are in demand for pulp or excelsior.

Basswood occurs very much scattered in this region and grows to advantage only on the best of sites. It may well be eliminated trom all others.

Beech is more abundant in the northern than in the southern portion of the region. It grows slowly and is iikely to become defective before maturity. It is perhaps the least liable to damage by the gipsy moth of any of the Class I trees. It is an excellent fuel and should be cut hearily when in the way of faster growing and more valuable trees.

Paper birch demands a large amount of light to grow well and is not abundant in mixed stands. When it occurs in abundance, it is in good demand for spool and novelty wood. It makes an excellent fuel, and scattered specimens could of ten be cut to the advantage of trees to be left.

Tumarack is nowhere abundant in the infested region. When dry it makes excellent kindling and a hot fire for a short time.

TREATMENT OF TREES IN CLASS II.

Class II is composed of eight species of trees on which gipsy-moth caterpillars in their earliest stages do not feed, but upon which they do feed in their later stages. Hence, if stands composed of these species hare in their vicinity no plants upon which tho young cater- 
pillars can feed, the stands may safely be considered immune from attack. Trees of this class may be grown safely in mixture with trees of Class IV.

Stands composed largely of one or more of the species of this class can be made inmune from gipsy moth attack by remoring the trees which may provide the young larra with food. There are many places where a considerable amount of cordwood could be cut most advantageously with this object in view.

Great care should be taken to protect and preserve young white pine and red pine, especially when they occur on poor soils. They often grow well on such soik, and if they are present the associated hardwoods which do not grow well on such sites, and which may be subject to caterpillar attack, may be cut beneficially. Red pine is not affected by the white-pine blister rust, which is spreading rery slowly among the white pines. If young white pines are giren a fair chance to grow, they will probably reach maturity before being seriously affected by the rust.

Chestnut grows well and yields a valuable product, but unfortunately is subject to attacks of the chestnut blight. It makes a poor grade of fuel, but with a shortage of the better grades an opportunity doubtless will be aflorded for the disposal of a considerable amount of this species.

\section{TREATMENT OF TREES IN CLASS III.}

Class III is composed of 20 species which are not particularly favored by gipsy moths, but upon which a small proportion of the larva may develop. Stands composed of any trees of this class alone or mixed with trees of Class IV, but containing no trees of Class I, would maintain only slight infestations and rarely, if ever, would be defoliated.

Blue beech, choke cherry, wild red cherry, hop hornbeam, and sassafras have no particular commercial value ordinarily and could well be converted into cordwood at this time.

Black: cherry has considerable commercial value, but its occurrence is generally rare. American elm and stippery elm are also generally scattered. Unless growing in very good soil, these trees could well be cut. Cottonwood, bitternut hickory, blach gum, silver maple, and silver poplar are rare. Bitternut hickory makes rery good fuel, but silver maple is not so good. The cutting or preservation of these species will have little effect in any respect.

The remaining trees of this class, namely, black and yellow birches, mockemut, pignut, and shagbark hickories, and red and sugar maples can be grown in comparative safety as far as the gipsy moth is concorned. The yellow birch, hickories, and sugar maple make the best 
of fuel, but they also produce excellent grades of lumber. With tuet of this class in great demand, there will be a temptation to cut young trees of this species. Dead, dying, and defective trees may well be removed now, but young and vigorous trees should be left to grow to larger and hence more valuable sizes.

TREATMENT OF TREES IN CLASS IV.

Class IV is composed of 21 spocies of trees on which the gipsy moth does not feed, or if it does, the amount is so slight as to be entirely negligible. Stands composed of trees of this group alone or combined with trees of Class II need cause no anxiety whatever as far as gipsymoth attack is concerned. Flowering dogwood, mountain laurel, mountain maple, striped maple, and sheepberry have little or no commercial value locally, and if large enough could well be cut for cordwood at this time.

Arborvitxe, black ash, and white cedar occur usually in or near swamps. They need no consideration as fuel.

Butternut, red cedar, locust, honey locust, and sycamore all require a large amount of light, for which reason they occur rarely in mixed woods, and they are of little importance as fuel.

Red ash, hackberry, American holly, red mulberry, tulip, and black walnut are so rare as to require little consideration.

In this region of degenerate woods, cuttings or thinnings among young trees should almost always be made with a view to improving the quality of the trees left, or the future growth. This moans that woodland should be kept fully stocked, but not crowded, with vigorous trees of the most valuable species. If inferior trees are cut out, care should be taken to protect seedlings and saplings of better species which may be on the ground, for otherwise, in the case of deciduous trees, sprouts will grow vigorously, and the same old conditions will reappear. When young growth of desirable species is not present, and no provision can be made for introducing better trees, it may often be better to leave the existing stand than to cut it.

It is realized that the foregoing suggestions can serve only in a very general way as a guide for thinning, but it is the desire of the Bureau of Entomology of the United States Department of Agriculture to aid the woodland owners of this region in every possible way, and the writers would be pleased as far as possible to confer with any owner in this region who is serionsly interested and will apply to them in person or by letter at Bureau of Entomology office, 964 Main Street, Melrose Highlands, Mass.

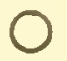


LIBRARY OF CONGRESS

|||||||||||||||||||||||||||||||||||||||||||||

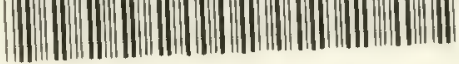

000092 3 4 1 36 